\title{
Perbandingan Metode Ekstraksi terhadap Kadar Flavonoid Total dan Aktivitas Antioksidan Batang Boehmeria virgata
}

\section{Comparison of Extraction Methods on Total Flavonoid Content and Antioxidant Activity of Boehmeria virgata Stem}

\author{
M.Rusdi ${ }^{1}$, Tahirah Hasan ${ }^{2}$, Ardillah $^{2}$, Evianti $^{2}$ \\ ${ }^{1}$ Jurusan Farmasi Fakultas Kedokteran dan Ilmu Kesehatan Universitas Islam Negeri Alauddin Makassar, Jl H.M. \\ Yasin Limpo No.36 Kecamatan Sombaopu Kabupaten Gowa, Sulawesi Selatan \\ ${ }^{2}$ Fakultas Matematika dan Ilmu Pengetahuan Alam, Universitas Islam Makassar, Jl. Perintis Kemerdekaan KM.9 \\ No.29, Tamalanrea Indah, Tamalanrea, Kota Makassar, Sulawesi Selatan
}

Kontak : muhammad.rusdi@uin-alauddin.ac.id

\begin{abstract}
ABSTRAK
Penelitian ini bertujuan untuk membandingkan metode ekstraksi terhadap kandungan flavonoid total dan aktivitas antioksidan ekstrak batang Boehmeria virgata. Batang Boehmeria virgata diekstraksi melalui dua metode ekstraksi yaitu refluks dan maserasi. Kandungan flavonoid total ditentukan dengan menggunakan metode aluminium klorida dan dihitung sebagai ekivalen kuersetin (QE). Aktivitas antioksidan diukur dengan menggunakan spektrofotometer UV-VIS. Hasil penelitian menunjukkan aktivitas antioksidan (Uji DPPH) ekstrak Boehmeria virgata (Forst) Guill yang diperoleh melalui metode refluks lebih baik daripada dengan metode maserasi ( $\mathrm{IC}_{50}$ pada $30,58 \mu \mathrm{g} / \mathrm{mL}$ ) karena menunjukkan kandungan flavonoid lebih tinggi (sampel 2,554 mg QE / g).
\end{abstract}

Kata Kunci : Boehmeria virgata, metode ekstraksi, Flavonoid, Antioksidan

\section{ABSTRACT}

The research aim is to comparise extraction methods on total flavonoid content and antioxidant activity of extract of Boehmeria virgata (Forst) Guill stem. Boehmeria virgata stem was extracted by two methods i.e reflux and maceration. Total flavonoid content determined using the aluminium chloride method and calculated as quercetin equivalents (QE). The antioxidant activity (DPPH assay) measured using a UV-VIS spectrophotometer. The results showed that the antioxidant activities of Boehmeria virgata extracts using reflux extraction was better than maceration extraction method $\left(I_{50}\right.$ at 30,58 $\left.\mu \mathrm{g} / \mathrm{mL}\right)$ since it shows higher total flavonoid content $(2,554 \mathrm{mg}$ $Q E$ / g sample).

Keywords : Boehmeria virgata, extraction method, total flavonoid content, antioxidant

\section{PENDAHULUAN}

Tumbuhan Parang Romang (Boehmeria virgata [Forst] Guill) dengan famili urticaceae sering digunakan sebagai obat kanker oleh masyarakat Sulawesi Selatan (Manggau, et al., 2011). Tumbuhan ini banyak ditemukan di daerah pegunungan Sulawesi Selatan.

Penelitian yang membahas tumbuhan Parang romang dan tumbuhan dari famili yang sama telah banyak dilaporkan. Ekstrak metanolik akar rami (Boehmeria nivea) menunjukkan efek antidiabetik, antihiperlipidemik, \& antioksidan (Sancheti, et al., 2011). B. nivea var. Nivea dan $B$. nivea var. Tenacissima, juga menunjukkan efek antioksidan berdasarkan pada peroksidasi lipid yang diinduksi $\mathrm{FeCl}_{2}$-askorbat pada homogenat hati tikus (Lin, M.H., Lo, \& Lin, 1998). Ekstrak B. platyphylla menunjukkan efek antiradikal bebas dengan $\mathrm{IC}_{50}$ sebesar $144,72 \mu \mathrm{g} / \mathrm{ml}$ dan kandungan flavonoid 
sebesar 21,12 \pm 0,23 mg kuercetin/g (Nazmul I, et al., 2016). Ekstrak etanol batang parang romang dengan dosis $50 \mathrm{mg} / \mathrm{kg}$ BB memiliki efek hipoglikemik, menurunkan glukosa darah mencit jantan (Rusdi, Jannah, Fauziah, \& Bariun, 2017). Penelitian lainnya menunjukkan ekstrak akar Parang Romang mengandung golongan alkaloid, terpenoid, fenolik, flavonoid (Rusdi, 2014)

Flavonoid merupakan senyawa metabolit sekunder yang terbentuk melalui jalur sikimat. Sikimat diproduksi dari unit sinnamoil-CoA dengan perpanjangan rantai menggunakan 3 malonil-CoA. Enzim khalkhon synthase menggabungkan senyawa ini menjadi khalkon. Khalkon adalah prekursor turunan flavonoid pada banyak tanaman (Dewick, 2002). Flavonoid berperan sebagai antioksidan dengan cara mendonasikan atom hidrogennya atau melalui kemampuannya mengkelat logam, biasanya dalam bentuk glukosida atau dalam bentuk aglikon (Cuppett, 1954). Antioksidan adalah senyawa yang dapat menghambat oksidasi dengan cara menangkap radikal bebas (Pokorny, Yanishlieva, \& Gordon, 2001)

Pengukuran kadar flavonoid total ekstrak dihitung dengan menggunakan spektrofotometer UV-Vis pada panjang gelombang maksimum dengan pembanding kuersetin. Pengujian aktivitas antioksidan ekstrak batang Parang Romang dilakukan dengan menggunakan metode peredaman radikal bebas DPPH untuk memperoleh nilai persen pengujian kapasitas antioksidan $\mathrm{IC}_{50}$.
Molekul DPPH merupakan senyawa radikal bebas yang stabil, memberikan warna ungu dengan absorbansi kuat pada panjang gelombang sekitar $520 \mathrm{~nm}$ (Molyneux, 2004).

Tujuan penelitian ini untuk mengetahui pengaruh perbedaan metode ekstraksi terhadap kadar flavanoid total ekstrak Batang Parang Romang dan aktivitas antioksidannya dengan metode peredaman radikal bebas DPPH.

\section{METODE PENELITIAN}

\section{Alat dan Bahan}

Alat-alat yang digunakan adalah seperangkat alat maserasi, seperangkat alat refluks, rotavapor $\left(I k a^{\circledR} R V \quad 10\right.$ basic $)$, spektrofotometer UV-Vis (Termo scientific evolution 201), dan timbangan analitik.

Bahan-bahan yang digunakan adalah Aluminium klorida, 1,1-difenil-2-pikrihidrazil (DPPH), air suling, etanol teknis (96\%), kalium asetat, kertas whatman, metanol, simplisia batang Parang romang (Boehmeria virgata (Forst) Guill), standar kuersetin dan vitamin $\mathrm{C}$.

\section{Pembuatan ekstrak}

\section{Metode Maserasi}

Sebanyak 300 g simplisia batang Parang Romang dimasukkan dalam wadah maserasi, dibasahkan sedikit dengan etanol $96 \%$, kemudian ditambahkan etanol 96\% hingga 2 Liter dan dibiarkan selama 2 hari pada temperatur kamar terlindung dari cahaya sambil sesekali diaduk, selanjutnya dilakukan penyaringan. Residu dilakukan remaserasi 
sebanyak 2 kali. Ekstrak cair yang diperoleh dikumpulkan, kemudian diuapkan dengan rotary evaporator, diperoleh ekstrak kental batang Parang Romang hasil maserasi (EPRM).

\section{Metode Refluks}

Sebanyak 150 gram simplisia batang parang romang, dimasukkan dalam labu alas bulat $1000 \mathrm{~mL}$, ditambahkan $800 \mathrm{~mL}$ etanol 96\%, direfluks selama 3 jam, didiamkan lalu disaring. Residu direfluks kembali dengan $700 \mathrm{~mL}$ etanol 96\% selama 3 jam, didiamkan lalu disaring. Ekstrak cair yang diperoleh dikumpulkan, kemudian diuapkan dengan rotary evaporator, diperoleh ekstrak kental batang Parang Romang (EPRR).

Analisis kuantitatif flavonoid dengan spektrofotometri UV-Vis

Larutan standar yang digunakan adalah kuersetin dengan konsentrasi 2, 4, 6, 8 dan 10 ppm. Penetapan kadar flavonoid dalam ekstrak etanol batang Parang Romang dilakukan dengan melarutkan 10,0 mg ekstrak dengan metanol volume dicukupkan hingga 10,0 mL dan dihomogenkan. Selanjutnya dipipet 1,0 $\mathrm{mL}$ dari larutan tersebut ke dalam labu ukur 10,0 mL untuk 3 replikasi. Masingmasing larutan ditambahkan dengan $0,2 \mathrm{~mL}$ larutan kalium asetat, 0,2 $\mathrm{mL}$ larutan aluminium klorida, $3 \mathrm{~mL}$ metanol dikocok hingga homogen. Air suling ditambahkan sampai tanda batas dan diamkan pada suhu ruangan selama 30 menit. Serapan diukur pada panjang gelombang 436,2 nm. Kadar flavonoid total dihitung dari kurva baku kuersetin. Kandungan flavonoid total dinyatakan sebagai jumlah $\mathrm{mg}$ ekuivalen kuersetin tiap gram ekstrak.

\section{Uji Aktivitas Antioksidan dengan Metode peredaman radikal bebas DPPH}

Pembuatan Larutan DPPH

Larutan DPPH 0,4 mM dibuat dengan cara menimbang DPPH sebanyak $15,8 \quad \mathrm{mg}$ dilarutkan dalam gelas kimia menggunakan metanol kemudian dimasukkan dalam labu tentukur $100 \mathrm{~mL}$ dan dicukupkan volumenya dengan methanol hingga tanda batas.

Uji Aktivitas Antioksidan Batang Parang Romang

Larutan sampel 500 ppm disiapkan dengan cara menimbang $25,0 \mathrm{mg}$ ekstrak yang dilarutkan dalam metanol sambil dihomogenkan, volume akhir di cukupkan dengan etanol hingga 50,0 mL. Larutan stock masing-masing dipipet $0,4 \mathrm{~mL} ; 0,8 \mathrm{~mL} ; 1,2$ $\mathrm{mL} ; \quad 1,6 \mathrm{~mL} ;$ dan 2,0 $\mathrm{mL}$ kemudian dicukupkan volumenya sampai $5,0 \mathrm{~mL}$ sehingga diperoleh konsentrasi $40 \mathrm{ppm}, 80$ ppm, 120 ppm, 160 ppm dan 200 ppm.

Pengujian dilakukan dengan memipet 0,5 $\mathrm{mL}$ larutan sampel lalu ditambah $3,5 \mathrm{~mL}$ larutan DPPH 0,4 mM. Campuran selanjutnya dihomogenkan dan serapannya diukur setelah 30 menit pada panjang gelombang $517 \mathrm{~nm}$.

\section{Uji Aktivitas Antioksidan Pembanding} Vitamin C

Larutan vitamin C 1000 ppm dibuat dengan cara menimbang sebanyak 10,0 mg vitamin $\mathrm{C}$ dan dilarutkan dengan metanol sambil dihomogenkan, dimasukkan dalam 
labu tentukur 10,0 mL, dicukupkan volumenya hingga tanda batas. Larutan 1000 ppm kemudian diencerkan menjadi 50 ppm. Larutan stock 50 ppm dipipet masing-masing 0,125 mL; 0,25 mL;0,5 mL; 1,0 mL; dan 2,0 $\mathrm{mL}$ dimasukkan dalam labu tentukur 5,0 mL kemudian dicukupkan volumenya hingga tanda batas sehingga diperoleh konsentrasi 1,25 ppm, 2,5 ppm, 5 ppm, 10 ppm dan 20 ppm.

Pengujian dilakukan dengan memipet 0,5 $\mathrm{mL}$ larutan vitamin $\mathrm{C}$ lalu ditambah $3,5 \mathrm{~mL}$ DPPH 0,4 mM. Campuran selanjutnya dihomogenkan dan serapannya diukur setelah 30 menit pada panjang gelombang $517 \mathrm{~nm}$.

Besarnya aktivititas antioksidan dinilai sebagai persen perendaman $50 \%\left(\mathrm{IC}_{50}\right)$ yang dihitung dari persamaan garis regresi linear antara konsentrasi (x) dan persen perendaman (y). Nilai persen perendaman dihitung dengan rumus :

$$
=\frac{\left(A_{\text {blangko }}-A_{\text {sampel }}\right)}{A_{\text {blangko }}} \times 100 \% .
$$

\section{HASIL DAN PEMBAHASAN}

Sampel yang digunakan dalam penelitian ini adalah batang Parang Romang. Ekstrak etanol batang Parang Romang diperoleh dengan dua metode ekstraksi yang berbeda yaitu maserasi dan refluks. Maserasi adalah cara ekstraksi sederhana yang dilakukan dengan merendam simplisia dalam pelarut yang sesuai pada temperatur kamar selama beberapa hari. Refluks adalah cara ekstraksi dengan pelarut yang sesuai pada temperatur titik didihnya selama waktu tertentu dan dalam jumlah pelarut terbatas yang relatif konstan terhadap pendingin balik.

Selanjutnya dilakukan uji kuantitatif untuk menentukan kadar flavonoid total. Uji ini diawali dengan pembuatan larutan standar kuersetin dengan berbagai seri konsentrasi. Kuersetin digunakan sebagai standar karena merupakan flavonoid golongan flavonol yang memiliki gugus keto pada atom $\mathrm{C}-4$ dan juga gugus hidroksil pada atom C-3 dan C-5 yang bertetangga. Aluminium klorida bereaksi

Tabel 1. Rendamen ekstrak etanol batang Parang Romang

\begin{tabular}{cccccc}
\hline No & Metode Ekstraksi & $\begin{array}{c}\text { Bobot sampel } \\
(\mathrm{g})\end{array}$ & $\begin{array}{c}\text { Jumlah pelarut } \\
(\mathrm{mL})\end{array}$ & $\begin{array}{c}\text { Bobot ekstrak } \\
(\mathrm{g})\end{array}$ & $\begin{array}{c}\text { Rendamen } \\
\text { ekstrak }(\%)\end{array}$ \\
\hline 1 & Maserasi & 300 & 5000 & 7,325 & 2,442 \\
\hline 2 & Refluks & 150 & 1400 & 3,107 & 2,071 \\
\hline
\end{tabular}

Tabel 2. Kadar flavonoid total Ekstrak etanol batang Parang Romang

\begin{tabular}{|c|c|c|c|c|}
\hline Sampel & Replikasi & $\begin{array}{l}\text { Abs } \\
(\mathrm{nm})\end{array}$ & $\begin{array}{c}\text { Flavonoid total } \\
(\mathrm{mg} / \mathrm{g})\end{array}$ & $\begin{array}{c}\text { Rata-rata } \\
(\mathrm{mg} / \mathrm{g})\end{array}$ \\
\hline \multirow{3}{*}{$\begin{array}{c}\text { Ekstrak hasil } \\
\text { Maserasi }\end{array}$} & $\mathrm{I}$ & 0,075 & 2,306 & \multirow{3}{*}{2,058} \\
\hline & II & 0,060 & 1,935 & \\
\hline & III & 0,060 & 1,935 & \\
\hline \multirow{3}{*}{ Ekstrak hasil Refluks } & $\mathrm{I}$ & 0,072 & 2,232 & \multirow{3}{*}{2,554} \\
\hline & II & 0,080 & 2,43 & \\
\hline & III & 0,103 & 3,000 & \\
\hline
\end{tabular}




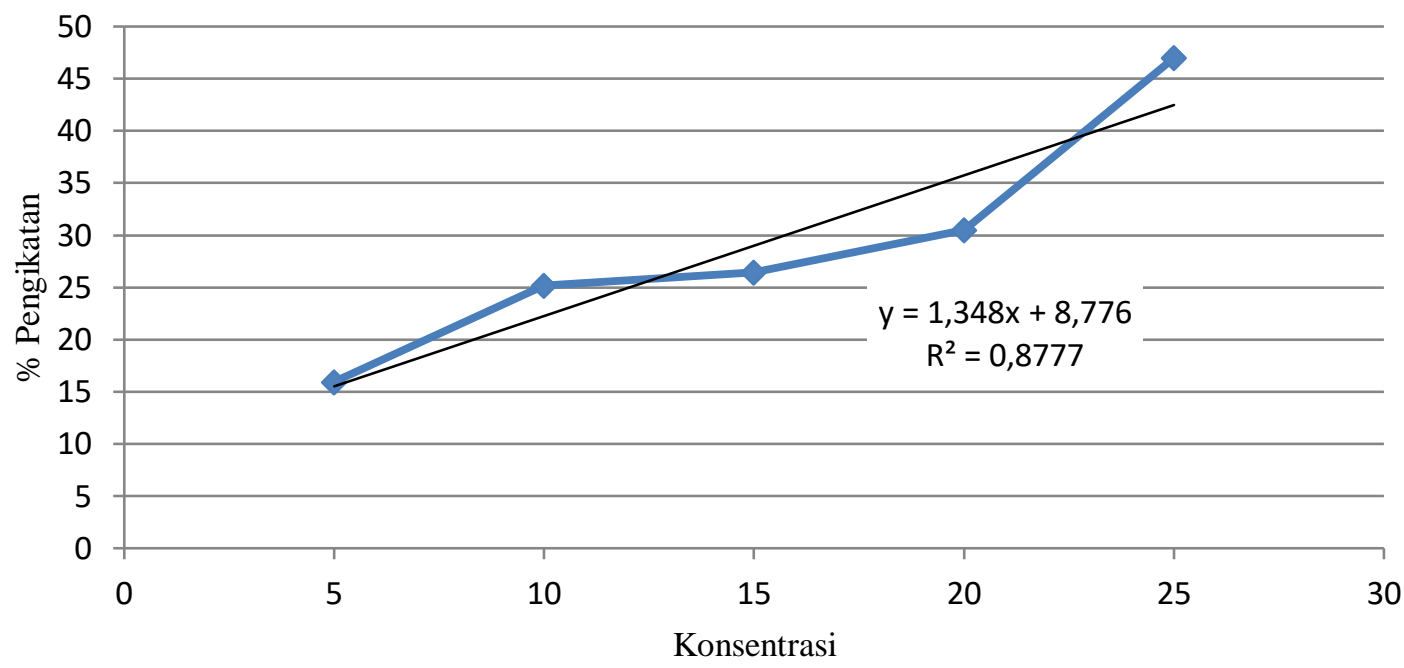

Gambar 1. Kurva Pengikatan Radikal Bebas Ekstrak Etanol Batang Parang Romang dengan Metode Refluks

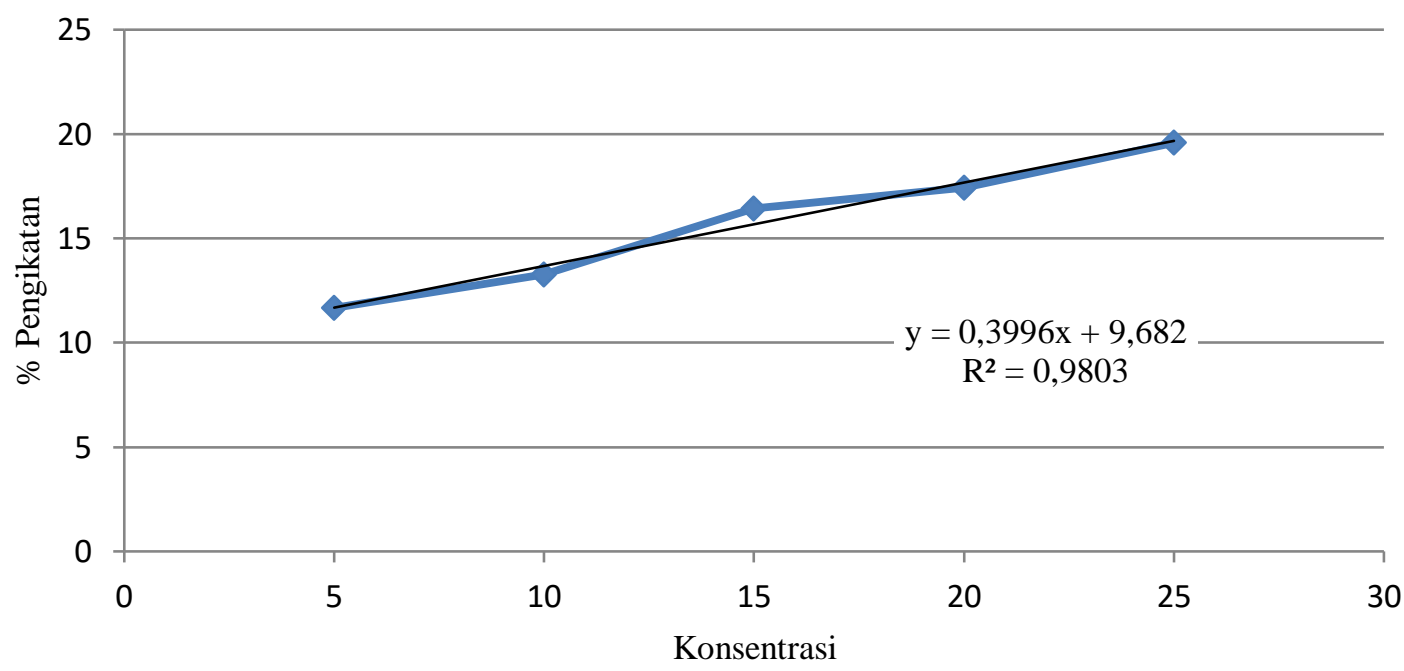

Gambar 2. Kurva Pengikatan Radikal Bebas Ekstrak Etanol Batang Parang Romang dengan Metode Maserasi

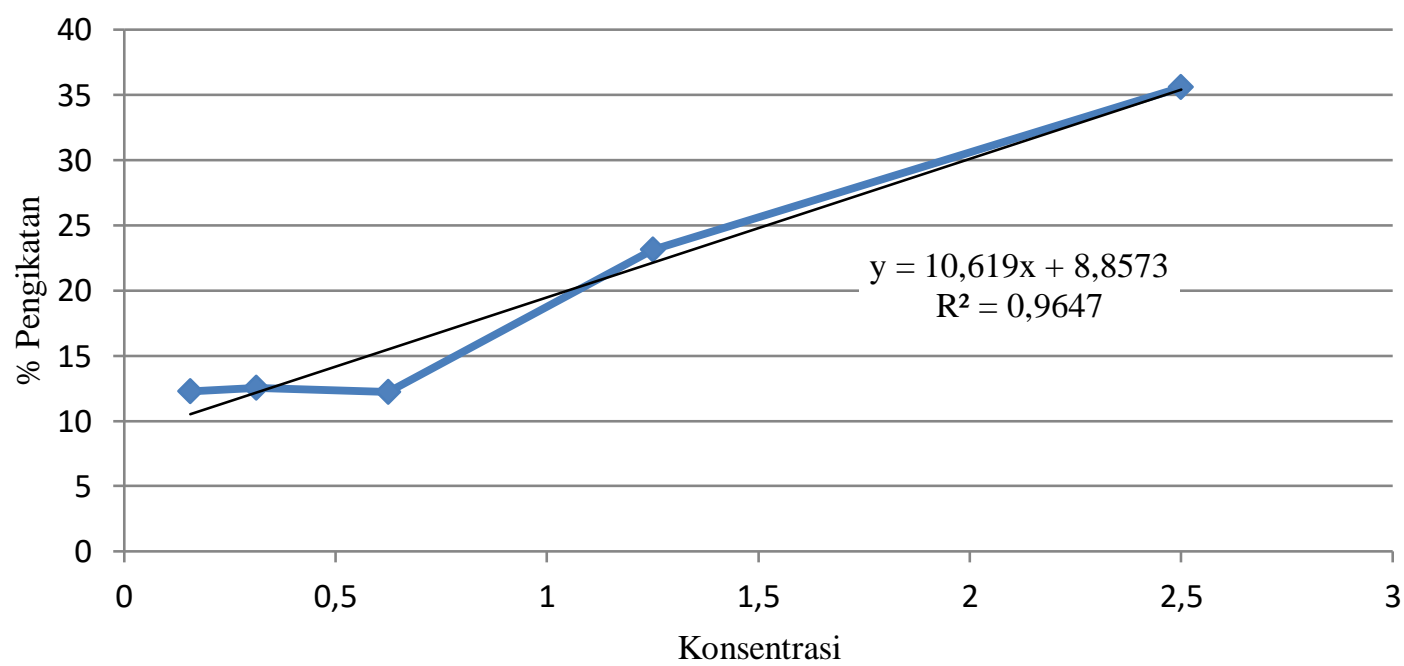

Gambar 3. Kurva Pengikatan Radikal Bebas Pembanding Vitamin C 
dengan kuersetin yang memberikan efek batokromik dengan melakukan pergeseran panjang gelombang kearah yang lebih panjang sehingga masuk ke dalam range panjang gelombang ultraviolet dan visibel (tampak).

Untuk pengukuran kadar flavonoid ekstrak etanol batang Parang Romang, masingmasing ditimbang $10 \mathrm{mg}$ ekstrak etanol batang Parang Romang dan dilarutkan dengan metanol p.a dalam labu ukur $10 \mathrm{~mL}$, volume dicukupkan sampai tanda batas. Dipipet $1 \mathrm{~mL}$ ke dalam labu ukur $10 \mathrm{~mL}$ untuk tiga konsentrasi, masing-masing ditambahkan metanol, kalium asetat, aluminium klorida dan dicukupkan volume sampai tanda batas dengan akuabides dan diukur pada panjang gelombang 436,2 $\mathrm{nm}$.

Hasil analisis kadar flavonoid total pada ekstrak etanol batang Parang Romang dengan spektrofotometer UV-Vis, untuk ekstrak hasil maserasi sebesar 2,058 $\mathrm{mgEK} / \mathrm{g}$ dan sampel hasil refluks sebesar 2,554 $\mathrm{mgEK} / \mathrm{g}$. Hasil analisis menunjukkan bahwa kadar flavonoid total pada ekstrak hasil refluks lebih besar dibandingkan dengan hasil maserasi. Hal ini kemungkinan disebabkan karena adanya proses pemanasan pada metode refluks, sehingga dapat meningkatkan kemampuan pelarut untuk mengesktraksi senyawasenyawa yang tidak larut dalam suhu kamar, sehingga penarikan senyawa lebih maksimal. Menurut Chew et al., hasil ekstraksi dipengaruhi beberapa faktor yaitu jenis, pelarut, konsentrasi pelarut, ukuran partikel, suhu, pH dan lama ekstraksi (Chew KK, 2011).

Pemilihan metode refluks dan maserasi dalam penelitian ini untuk membandingkan aktivitas antioksidan ekstrak hasil refluks dan maserasi. Ekstrak hasil refluks dan maserasi kemudian dilakukan uji aktivitas antioksidan

Tabel 3. Aktivitas Antioksidan terhadap Vitamin C dan Ekstrak Parang Romang

\begin{tabular}{|c|c|c|c|c|}
\hline $\begin{array}{c}\text { Standar } \\
\text { (Pembanding) }\end{array}$ & $\begin{array}{l}\text { Konsentrasi } \\
(\mathrm{ppm})\end{array}$ & $\begin{array}{l}\text { Absorbansi } \\
\text { (nm) }\end{array}$ & $\begin{array}{c}\text { Pengikatan } \\
\text { Radikal Bebas } \\
(\%)\end{array}$ & $\begin{array}{l}\mathrm{IC}_{50} \\
(\mathrm{ppm})\end{array}$ \\
\hline \multirow{5}{*}{ Vitamin C } & 0,15 & 1,198 & 12,29 & \multirow{5}{*}{3,87} \\
\hline & 0,31 & 1,195 & 12,51 & \\
\hline & 0,62 & 1,199 & 12,22 & \\
\hline & 1,25 & 1,05 & 23,13 & \\
\hline & 2,5 & 0,88 & 35,47 & \\
\hline \multirow{5}{*}{$\begin{array}{c}\text { Ekstrak hasil } \\
\text { Refluks }\end{array}$} & 5 & 1,148 & 15,95 & \multirow{5}{*}{30,58} \\
\hline & 10 & 1,022 & 25,15 & \\
\hline & 15 & 1,005 & 26,42 & \\
\hline & 20 & 0,954 & 30,47 & \\
\hline & 25 & 0,724 & 46,99 & \\
\hline \multirow{5}{*}{$\begin{array}{c}\text { Ekstrak hasil } \\
\text { Maserasi }\end{array}$} & 5 & 2,371 & 11,67 & \multirow{5}{*}{100,89} \\
\hline & 10 & 2,328 & 13,27 & \\
\hline & 15 & 2,243 & 16,43 & \\
\hline & 20 & 2,21 & 17,67 & \\
\hline & 25 & 2,159 & 19,58 & \\
\hline
\end{tabular}


dengan metode peredaman radikal bebas DPPH. Metode peredaman radikal bebas DPPH digunakan dalam penelitian ini karena memiliki beberapa kelebihan diantaranya sederhana, mudah, cepat, peka, dan menggunkan sedikit sampel. DPPH merupakan suatu molekul dalam keadaan radikal yang memiliki warna ungu dapat berubah

menjadi stabil dengan warna kuning oleh reaksi senyawa antioksidan dengan mendonorkan satu atom hidrogen pada DPPH sehingga terjadi peredaman radikal bebas DPPH. Perubahan warna ini akan memberikan perubahan absorbansi pada Panjang gelombang maksimum DPPH menggunakan spektrofotometer UV-Vis sehingga akan diketahui nilai aktivitas peredaman radikal bebas yang dinyatakan dengan nilai $\mathrm{IC}_{50}$. Nilai $\mathrm{IC}_{50}$ didefnisikan sebagai besarnya konsentrasi senyawa uji yang dapat meredam radikal bebas sebanyak 50\%. (Molyneux, 2004).

Hasil analisis aktivitas antioksidan ekstrak etanol batang parang romang dengan metode DPPH menunjukkan bahwa hasil refluks memiliki aktivitas antioksidan dengan nilai
IC $_{50} 30,58 \mu \mathrm{g} / \mathrm{mL}$. Ekstrak etanol batang parang romang dengan metode maserasi memiliki aktivitas antioksidan dengan nilai $\mathrm{IC}_{50} \quad 100,27 \mu \mathrm{g} / \mathrm{mL}$. Hal ini menujukkan EBHR dikategorikan sebagai antiradikal bebas kuat karena memiliki nilai IC $_{50}$ antara 10-50 $\mu \mathrm{g} / \mathrm{mL}, \quad$ sedangkan EBHM dikategorikan sebagai antiradikal bebas lemah karena memiliki nilai $\mathrm{IC}_{50}$ antara 100 $250 \mu \mathrm{g} / \mathrm{mL}$ (Phongpaichit, et al., 2007)

Pembanding vitamin $\mathrm{C}$ memiliki aktivitas antioksidan dengan nilai $\mathrm{IC}_{50}$ sebesar 3,87 $\mu \mathrm{g} / \mathrm{mL}$. Besarnya antioksidan ekstrak etanol berbeda dengan besarnya aktivitas antioksidan vitamin C. Perbedaan ini dapat diartikan bahwa vitamin $\mathrm{C}$ memiliki aktivitas antioksidan lebih kuat dibandingkan ekstrak etanol. Vitamin $\mathrm{C}$ merupakan antikosidan yang bekerja sebagai oxygen scavengers, yaitu mengikat oksigen sehingga tidak mendukung reaksi oksidasi. Dalam hal ini, vitamin $\mathrm{C}$ akan mengadakan reaksi dengan oksigen yang berada dalam system sehingga jumlah oksigen akan berkurang. Selain vitamin $C$, senyawa yang bekerja sebagai oxygen scavengers diantaranya askorbil palminat, asam eritorbat, dan sulft (Gordon,

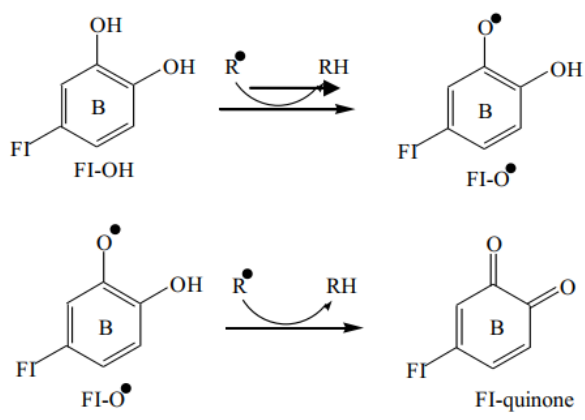

Gambar 4 . Reaksi penangkapan radikal bebas oleh senyawa flavonoid (Pietta, 2000) 
1990)

Reaksi DPPH dengan atom hidrogen yang terdapat pada antioksidan dapat membuat larutan DPPH menjadi berkurang reaktivitasnya, yang dapat ditunjukkan dengan memudarnya warna ungu menjadi kuning (Molyneux, 2004). Uji aktivitas antioksidan ini menunjukkan bahwa senyawa aktif yang terdapat dalam ekstrak etanol batang Parang romang mampu menangkal radikal bebas DPPH dengan cara mendonorkan atom hidrogen sehingga berubah menjadi DPPH bersifat non radikal.

\section{KESIMPULAN}

Kadar flavonoid total ekstrak etanol Parang Romang dengan metode refluks (2.554 mgEK / g) lebih besar dibandingkan metode maserasi (2,058 mgEK / g)dengan nilai berturut-turut. Aktivitas antioksidan ekstrak etanol Parang Romang yang diperoleh melalui metode refluks ( IC $_{50} 30,58 \mu \mathrm{g} / \mathrm{mL}$ ) lebih baik dibandingkan dengan metode maserasi ( $\mathrm{IC}_{50} 100,89 \mu \mathrm{g} / \mathrm{mL}$ ).

\section{DAFTAR PUSTAKA}

Cuppett, S. M. (1954). Natural Antioxidant Are They Reality. In Shahidi, F: Natural Antioxidants, Chemistry, Health Effect and Applications, . AOCS Press, Champaign, Illinois, 12-24.

Dewick, P. (2002). Medicinal Natural Products, A Biosynthetic Approach.

Gordon, M. H. (1990). The mechanism of antioxidants action in vitro. . In B. Hudson, Food antioxidants (pp. 1-18). London: Elvesier Applied Science.

Lin, C., M.H., Lo, T., \& Lin, J. ( 1998). Evaluation of the hepatoprotective and antioxidant activity of Boehmeria nivea Var. nivea and B. nivea Var, tenacissma. $J$. Ethnopharmacol, 9-17.

Manggau, M., Hasan, Wahyudin, E., Haryono, K., Mufidah, \& Lukman. (2011). Efek Farmakologi Tanaman Antikanker yang digunakan oleh Masyarakat Sulawesi Selatan. Makassar: Balitbangda Sulawesi Selatan.

Molyneux, P. (2004). The Use Of The Stable Free Radical Diphenylpicrylhidrazyl (DPPH) For Estimating Antioxidant Activity. J. Sci. Technol Vol. 26 (2), 211219.

Nazmul I, M., Mohammad Shah Hafez Kabir, S. M., Hasan, M., Samrat, E. K., Habib, I. B., Jony, M. N., . . . Rahman, M. M. (2016). Total Phenol, Total Flavonoid Content and Antioxidant Potential of Methanol Extract of Boehmeria Platyphylla D Don Leaves. World Journal of Pharmaceutical Research 5(5), 334344.

Phongpaichit, S., Nikom, J., Rungjindamai, N., Jariya, S., Hutadilok, n., Rukaschaisirikul, v., \& kirtikara, k. (2007). Biological activities of extract from endophytic fungi isolated from Garcinia plants. FEMS Immunology Dan Medical Microbiology, volume 51, Issue 3, 517525.

Pietta, P. (2000). Flavonoids as Antioxidants, J. Nat. Prod. J. Nat. Prod. 63 (7), 10351042.

Pokorny, J., Yanishlieva, N., \& Gordon, M. (2001). Antioxidant in Food: Practical Application. Boca Raton: CRC Press.

Rusdi, M. (2014). skrining fitokimia dan uji toksisitas akar Parang Romang (Boehmeria virgata (Forst) Guill) terhadap larva udang Artemia salina L. Farbal "Farmasi dan Bahan Alam, 68-71.

Rusdi, M., Jannah, J., F. N., \& Bariun, H. (2017). Uji Efek Hipoglikemik Ekstrak Etanol Akar Parang Romang (Boehmeria Virgata (Forst) Guill) Terhadap Mencit Jantan. Jurnal Farmasi FIK UIN Alauddin Makassar Vol.5 No.1.

Sancheti, S., Sancheti, S., Bafna, M., Kim, H., You, Y., \& Seo, S. (2011). Evaluation of Antidiabetic, Antihyperlipidemic and Antioxidant Effects of Boehmeria nivea 
(L.) Gaudich., Urticaceae, Root Extract in Streptozotocin-induced Diabetic Rats. Brazilian Journal of Pharmacognosy, 21(1), 146-154.
Winarsi, H. (2007). Antioksidan Alami dan Radikal Bebas: Potensi dan Aplikasinya dalam Kesehatan. Yogyakarta: Penerbit Kanisius. Hal: 21-23. 